\title{
Convergence, Dynamics and Geography of Economic Growth: The Case of Municipalities in Rio Grande do Norte, Brazil
}

\author{
by
}

\section{Dorte Verner and Edinaldo Tebaldi ${ }^{1}$}

\author{
The World Bank
}

World Bank Policy Research Working Paper 3302, May 2004

The Policy Research Working Paper Series disseminates the findings of work in progress to encourage the exchange of ideas about development issues. An objective of the series is to get the findings out quickly, even if the presentations are less than fully polished. The papers carry the names of the authors and should be cited accordingly. The findings, interpretations, and conclusions expressed in this paper are entirely those of the authors. They do not necessarily represent the view of the World Bank, its Executive Directors, or the countries they represent. Policy Research Working Papers are available online at http://econ.worldbank.org.

\footnotetext{
${ }^{1}$ We are grateful to the Secretariat of Planning, Rio Grande do Norte for assistance on data and other information and Joachim von Amsberg for valuable comments and suggestions on earlier drafts.
} 


\begin{abstract}
:
Analyses of municipal GDP growth in Rio Grande do Norte in the Northeast of Brazil during 1970-96 reveal that the cross-section dispersion of per capita income increased over time. Although the analysis indicates some spatial dependence in income, it is small and has a downward trend, indicating that the growth path is only weakly determined by geographical links in Rio Grande do Norte. Moreover, dynamic analysis, based on the Markov chain transition matrix, show that the probability of a municipality moving from a poor income class to a rich class is very small and vice-versa. Municipalities located in the middle-income class have high mobility, but there is no strong evidence indicating direction. Public policy should include assisting the rural families by providing them education and training that increases their opportunities for employment. There should also be policies to assist poor and/or unskilled migrants to integrate fully into the modern economy in the urban areas through skill development training and education.
\end{abstract}




\section{Introduction}

Rio Grande do Norte (RN), in Northeast Brazil, has made commendable progress toward increasing incomes over the last half century. Over this period, its per capita income grew by 3.9 percent annually, higher than Brazil's average of 3.4 percent. During the last two decades alone, the share of the population that was classified as extremely poor fell by 20 percent. Infant mortality and illiteracy rates fell by an astounding 71 and 41 percent, respectively, over this period. That $\mathrm{RN}$ has been able to achieve all this without incurring much debt is particularly laudable.

Despite these achievements, RN's income per capita is less than half that of Brazil as a whole. Similarly, its poverty is disconcertingly high and well above the national average. About 40 percent of its population lives in extreme poverty, meaning that the household does not have sufficient income to purchase a minimum food basket of 2,288 calories per day.

Policies to stimulate economic growth and employment must remain the backbone of RN's efforts to reduce poverty. While national economic policies play a major role in stimulating growth, the state contribute by encouraging the federal and municipal governments to implement policies and programs that are oriented to enhancing RN's infrastructure and human capital in an effective manner. In addition, it can strive to ensure that its social programs aimed at providing a safety net for those who are well below the poverty line are well targeted and effective.

The purpose of this paper is to analyze the economic growth of Rio Grande do Norte. More specifically we analyze: a) whether poor municipalities are catching up with rich municipalities, and b) whether geography matters for economic development in the state.

The paper is organized as follows: Section 2 gives a brief description of RN; Section 3 presents the data; Section 4 gives a descriptive growth analysis; Section 5 analyzes per capita income convergence by using traditional and spatial approaches; and, finally, Section 6 reports conclusions and policy recommendations.

\section{Background}

\section{Geography and Climate}

The state of Rio Grande do Norte (RN), starts where the northeastern sugar belt ends. It covers 0.62 percent of Brazil's total area, or 53,307 square kilometers, and has a history and landscape different from the states to its south. $\mathrm{RN}$ is famous for its beaches and dunes, and the coast is dryer and less green than in the states to the south. Where once there were coastal forests (mata atlântica), there are now dry scrub savanna (caatinga) vegetation and cashew orchards. Most of the state is level or gently rolling, with few 
elevations exceeding 700 meters. About 20 percent of $\mathrm{RN}$ is considered suitable for cultivation, and 75 percent is either under pasture or has potential for such use.

Geographically, the state is rather heterogeneous, comprising two great ecosystems - the Coastal Zone and the semiarid Sertão Zones. The Coastal Zone is a humid area, with average precipitation of 2,000 millimeters per year. Although it only accounts for 10 percent of the state's area, more than half the state's 2.8 million inhabitants resided in the Coastal Zone in 2000. Major cities and industry are located in this area, as well as some high-value agriculture. Coastal soils are formed from sedimentary rock and are thus deep and permeable, making them suitable for agriculture. Despite substantial degradation of the flora in the coastal area, there are still some forests and wetlands remaining.

The rest of the population lives in the Sertão, which has relatively few natural resources and scattered caatinga vegetation. Soils in the interior are generally shallow and impermeable, and underground aquifers are scarce and often saline. Agricultural activity predominates, but climatic variability makes it risky. Precipitation ranges between 300 and 800 millimeters per year. However, rainfall is irregular and tends to be concentrated in a few, brief storms, resulting in high rates of erosion and water loss. Much of the inland area experiences water deficits lasting 8 to 12 months. Droughts and floods are frequent. On average, only two years in every decade are free from drought. Droughts cause crop failures and unemployment, which exacerbate poverty and cause social problems such as malnutrition and migration (Magalhães 1992).

\section{Economy and People}

RN has a population of 2.8 million (1.6 percent of Brazil's total). The people are called Potiguars, after an Indian tribe that once resided in the state (Box 1.1). In 1999, the state's GDP was about R $\$ 7.6$ billion, equivalent to about 6 percent of the Northeast's GDP, and well under 1 percent of the country's GDP. About two-fifths of the state's GDP is derived from services and another one-third from industry. Agriculture accounts for only 7 percent of GDP but about 18 percent of employment. ${ }^{2}$

\footnotetext{
${ }^{2}$ Contas Regionais do Brasil, (Instituto Brasileiro de Geografia e Estatística, IBGE).
} 


\section{Box 1.1: Historic Background:}

\section{From a Salt/Cattle/Sugar Economy to a Diversified Industrial/Services Economy}

The Potiguar Indians were hunters, fishermen, and subsistence farmers (manioc was the main crop). Cattle raising was a very important activity in the Capitania (the geographical unit before states were formed) of Rio Grande do Norte. Sugarcane was an important crop in the Northeast region, but it was never big in $\mathrm{RN}$, which for much of the $16^{\text {th }}$ century was largely controlled by the French, who were in the area in their search for wood, principally pau-brasil (Brazil wood).

The Portuguese took control of the area in 1598 and consolidated their hold with the construction of the Forte dos Reis Magos a year later. However, the area came under Dutch domination from 1633 until 1654. This period saw an expansion of salt production and cattle rearing with backward linkages to sugar production, the first two of which became the chief activities when the Portuguese won back control in 1654. Cattle were an important source of energy in sugar production, and also supplied meat and leather. The cattle era ended with the drought in 1845 . Throughout historyespecially 1845, 1877, and 1975-76 - drought has been a determining factor in RN's fortunes.

In the late $17^{\text {th }}$ century a rebellion by Indians against enslavement, the Confederação dos Cairis, affected RN and neighboring provinces. However, it was put down by troops led by bandeirantes. From 1701, the Capitania of RN became part of the Capitania of Pernambuco. In 1824, soon after Brazilian independence, $\mathrm{RN}$ received provincial status and in 1889, it became a state of Brazil.

At the beginning of the $19^{\text {th }}$ century, RN's main exports were cotton, salt, sugar, and wax from the carnauba tree. By the mid- $19^{\text {th }}$ century, the Portuguese crown devastated the economy by forbidding the export of salt and dried beef. The state did not recover until Brazilian independence in 1822 removed the prohibition. By the mid- $19^{\text {th }}$ century cotton had become a very important crop, especially in the Seridó and Agreste regions. RN was Brazil's leading cotton producer, and continued to be until 1930, when stagnation set in as São Paulo abandoned its coffee production and started to grow cotton.

At the beginning of the $20^{\text {th }}$ century, cotton, salt, and carnauba wax were the main products of the state. By the middle of the century industrialization began in Northeast Brazil. Agricultural products such as cotton, sugar, sisal, and nuts were driving the creation of the industrial and service sectors in RN. Cotton was the most important crop, and led to the founding of textile manufacturing, which is still one of the most important industrial sectors in the state. In $\mathrm{RN}$, the first cotton processing factories were in place in 1910, and by 1920 there were about 200. After World War I the number of factories mushroomed, reaching 1,042 in 1950 .

$\mathrm{RN}$ is well located for domestic trade and international trade, particularly its northeastern region, which is growing in both population and purchasing power. RN's economy is fairly diversified and exports industrial products (such as textiles, shoes, oil, and salt), agricultural products (such as melons and fisheries), and service products (such as tourism) to other states within Brazil and overseas. Exports to markets overseas, helped by access to various ports in the area and a new international airport, are growing rapidly.

Despite substantial progress in poverty reduction in the past two decades, about 40 percent of the population in $\mathrm{RN}$ is indigent - unable to afford the basic daily caloric intake. ${ }^{3}$ Poverty is more widespread in rural areas, where 53.5 percent of the population

\footnotetext{
${ }^{3}$ This is the headcount poverty ratio (P0), which measures the proportion of people below the poverty line. Here, the indigence poverty line is used, which is based on the monetary cost of a "minimum food-
} 
is unable to pay for a minimum basket of food. In urban areas, where 73 percent of the population resides, the incidence of poverty is 33.5 percent. Similarly, 26 percent of the population older than age 15 is still illiterate and the infant mortality rate is still high at 48.7 per 1,000 live births - much higher than Brazil's average but slightly better than the Northeast average.

\section{Data Sources}

We apply municipality level data for 150 municipalities in Rio Grande do Norte. The different sources of data are cited below.

\section{GDP}

The source of municipality GDP data $(1970,1975,1980,1985,1990$ and 1996) is www.ipea.gov.br. The data are in US dollars of 1998. More information about methodological procedures, etc. used to generate the data can be obtained at IPEA's web site.

\section{Population}

The data on population of the municipalities are from IBGE Censuses of 1970, 1980, and 1991 and IBGE Contagem in 1996. One part of this data is available at www.ibge.gov.br and another part was tabulated by the authors using the software "WinR+ 2000 Lite" and the CD-Rom bases of IBGE. For the years 1975, 1985 and 1990, data are interpolated using the geometric mean rate of growth of the respective decade.

\section{Overall Trend and Location Structure of Growth}

Brazil was the fastest-growing country in the world during $1930-1995,{ }^{5}$ with an average growth rate of 6.1 percent per year, with much of the growth occurring prior to the 1980s. Although the Northeast also grew, the region remains much poorer than the national average. In 1998, the Northeast's GDP of R $\$ 119$ billion was about 13 percent of Brazil's GDP of R \$914 billion, while its population was 29 percent of Brazil's population. Thus the per capita GDP of the Northeast was only 47 percent of per capita GDP in Brazil.

RN's per-capita income has hovered around 45 percent of Brazil's per capita GDP over the last five decades (Figure 4.1). The state's annual per capita growth averaged 3.6 percent from 1947 to 1998, higher than for Brazil (2.9 percent) or the Northeast (3.0

\footnotetext{
basket" equal to the Food and Agriculture Organization (FAO) minimum caloric intake of 2,288 per day. This corresponds to a monthly per-capita income of about R $\$ 73$ in 1999, the most recent year for which household information is available.

${ }^{4}$ It is a freeware software available for download in the ECLAC web site: www.eclac.org/software/

${ }^{5}$ See Abreu and Verner (1997).
} 
percent). As a result, its GDP per capita over this period, relative to that of Brazil, increased from 43 to 49 percent. In 1999, RN's GDP was R $\$ 7.6$ billion, or 6.0 percent of the Northeast's GDP.

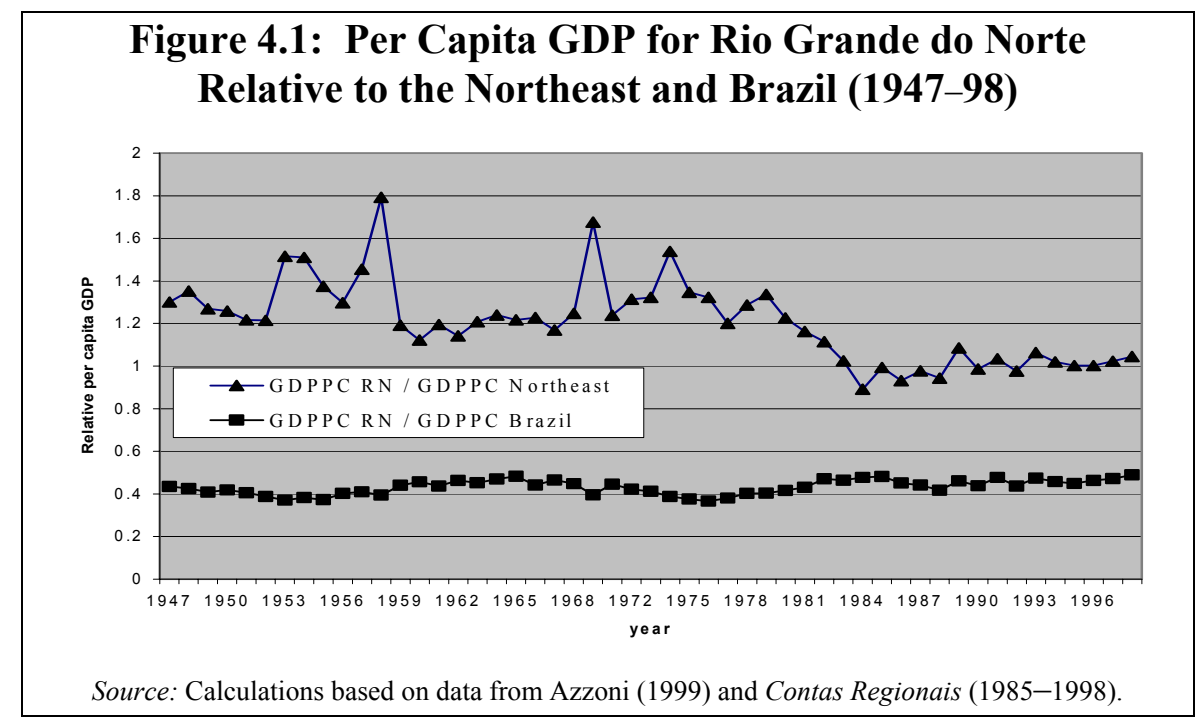

Figure 4.1 shows the recent performance of RN's per capita income relative to the Northeast's. The data show strong growth compared to the rest of the states in the Northeast from 1947 to the end of the 1970s. During this period, RN's per capita income ranged from 90 to 180 percent of the per capita income of the Northeast. After the collapse of cotton production due to the boll weevil pest in the late 1970s, RN's GDP per capita as a share of the Northeast's GDP reached a historic low of about 90 percent. The economy recovered slightly after 1984 and is currently on a positive path, but the ratio of its per capita GDP to the Northeast per capita GDP of 105 percent is well behind its ratio five decades ago (Figure 4.1).

Table 4.1: Real Per-Capita GDP Growth in the Northeast, 1985-98

\begin{tabular}{lccc}
\hline & $\begin{array}{c}\mathbf{1 9 8 5 - 9 0} \\
\mathbf{( \% )}\end{array}$ & $\begin{array}{c}\mathbf{1 9 9 0 - 9 8} \\
\mathbf{( \% )}\end{array}$ & $\begin{array}{c}\mathbf{1 9 8 5 - 9 8} \\
\mathbf{( \% )}\end{array}$ \\
\hline Brazil & 1.72 & 2.49 & 2.34 \\
Northeast & 0.17 & 2.65 & 1.77 \\
\hline
\end{tabular}




$\begin{array}{lllc}\text { Piauí } & 3.92 & 3.34 & 3.83 \\ \text { Ceará } & 0.69 & 5.27 & 3.66 \\ \text { Paraíba } & 4.53 & 1.78 & 3.08 \\ \text { Maranhão } & 2.96 & 2.38 & 2.80 \\ \text { Pernambuco } & 1.97 & 2.72 & 2.60 \\ \text { Rio Grande do Norte } & 0.32 & 2.96 & 2.04 \\ \text { Bahia } & -1.19 & 1.83 & 0.65 \\ \text { Alagoas } & -1.49 & 1.91 & 0.57 \\ \text { Sergipe } & -5.93 & 1.99 & -1.34 \\ \text { Source: Calculated with data from Contas Regionais and Central Bank of Brazil. }\end{array}$

Per capita growth has been impressive in recent years. Between 1990 and 1998, annual GDP growth in RN was 3.0 percent, compared to 2.7 percent for the Northeast and 2.5 percent for Brazil (Table 4.1). It was higher than in the richest states of the Northeast, Bahia and Pernambuco, but below those of some of the poorest states, Ceará and Piaui.

The strong relationship between Brazil's aggregate growth and RN's economic progress in the last five decades reflects the response to common macroeconomic forces. Countrylevel policies (for example, macromanagement) imply a strong correlation between state growth and country growth. Growth in the Northeast, outperformed by other regions such as Center-West, has been lower than the Brazilian average. Nevertheless, RN's growth performance has been among the better in the Northeast during the last decade, suggesting that some convergence took place in the 1990s. The main factor in both RN's and Brazil's growth performance in the 1990s was the macroeconomic stabilization that followed the inflation-beating Real Plan of 1994. This may suggest that RN's economy experienced a very limited transformation in the past decade, which positively affected the growth path of the state.

\section{Sectoral Sources of Growth and Employment}

An understanding of the sectoral sources of growth and employment is useful in designing a strategy to accelerate growth and employment. Over the last two decades the economy has shifted away from agriculture, industry, and mining toward services (Figure 4.2 and Table 4.2). 


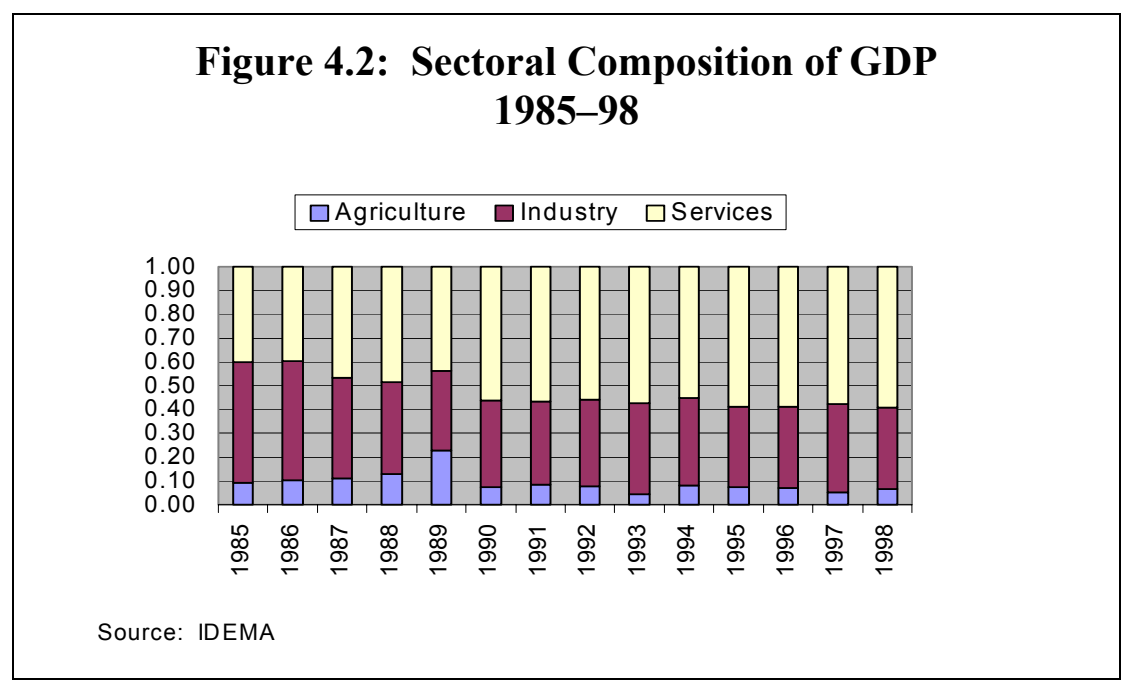

\begin{tabular}{|l|c|c|c|}
\hline \multicolumn{4}{|c|}{ Table 4.2: Sectoral GDP, 1985-1998 } \\
\hline Sector & $\begin{array}{c}\mathbf{1 9 8 5} \\
\text { (R\$ million) }\end{array}$ & $\begin{array}{c}\mathbf{1 9 9 8} \\
\text { (R\$ million) }\end{array}$ & $\begin{array}{c}\text { Annual } \\
\text { Growth } \\
\text { (Percent) }\end{array}$ \\
\hline Industry & 2047 & 2340 & 1.0 \\
\hline Services & 1629 & 4052 & 7.3 \\
\hline Agriculture & 375 & 448 & 1.4 \\
\hline TOTAL & 4051 & 6840 & 4.1 \\
\hline \multicolumn{4}{|l|}{ Source: Contas Regionais, IBGE } \\
\hline
\end{tabular}

The service sector has been the most dynamic in the last two decades. It increased its share of GDP from 40 percent in 1985 to 59 percent in 1998 while the shares of industry and agriculture declined from 50 to 34 percent and from 9 to 7 percent, respectively.

Economic growth experienced in the last decades in $\mathrm{RN}$ is far from homogeneous throughout the state. The large regional differences within the state are associated with the expansion of economic activities in a few of the areas away from the Sertão. Of the eight zones in RN only two, Litoral Oriental and Mossoroense, experienced an aboveaverage expansion of output during 1970-96. In the past three decades these two veryfast-growing zones on the coast also experienced by far the largest population inflow of the eight zones (Table 4.3). The largest real GDP growth, above 500 percent during 1970-96, took place in the capital region (Litoral Oriental) where the industry and service sectors are particularly strong. The second-largest GDP expansion, 312 percent during 1970-96, occurred in the zone of Mossoró, where, in particular, oil, gas, and irrigated agriculture have expanded rapidly in some municipalities and created opportunities for the population. Litoral Oriental and Mossoroense had the largest population growth, 151 and 79 percent, respectively, during 1970-2000 (Table 4.3).

Table 4.3: Real GDP, Population, And Poverty in RN's Eight Zones, 1970-2000 


\begin{tabular}{|c|c|c|c|c|c|c|c|c|}
\hline \multirow[b]{2}{*}{ Zone } & \multicolumn{3}{|c|}{ Population } & \multicolumn{2}{|r|}{ Poverty } & \multicolumn{3}{|c|}{ Real GDP Growth (\%) } \\
\hline & 1970 & 2000 & $\begin{array}{c}\text { Annual } \\
\text { Growt } \\
\text { h } \\
1970- \\
2000 \\
(\%) \\
\end{array}$ & $\begin{array}{c}\text { Per } \\
\text { Capita } \\
\text { GDP } \\
1996 \\
\text { (R\$) }\end{array}$ & $\begin{array}{c}\% \text { Earning } \\
<\text { One } \\
\text { minimum } \\
\text { salary } \\
2000\end{array}$ & $\begin{array}{c}1980- \\
90\end{array}$ & $\begin{array}{c}1990- \\
96\end{array}$ & $\begin{array}{c}1970- \\
96\end{array}$ \\
\hline $\begin{array}{c}\text { Serras } \\
\text { Centrais } \\
\end{array}$ & 71,123 & 90,667 & 0.81 & 776.2 & 88.3 & -1.51 & 8.02 & 3.93 \\
\hline $\begin{array}{l}\text { Alto do } \\
\text { Apodi }\end{array}$ & 176,653 & 223,969 & 0.79 & 892.7 & 75.0 & -1.67 & 6.37 & 4.4 \\
\hline Agreste & 219,550 & 285,166 & 0.88 & 830.5 & 67.3 & -1.05 & 3.74 & 2.84 \\
\hline Caicó & 88,901 & 120,562 & 1.02 & 1353.8 & 25.9 & 0.73 & 3.08 & 3.49 \\
\hline $\begin{array}{c}\text { Litoral } \\
\text { Oriental }\end{array}$ & 505,794 & $1,271,156$ & 3.12 & 3334.1 & 44.0 & 6.3 & 2.23 & 7.33 \\
\hline $\begin{array}{l}\text { Litoral } \\
\text { Norte }\end{array}$ & 125,013 & 168,980 & 1.01 & 1783.2 & 51.7 & 1.83 & 1.35 & 2.84 \\
\hline $\begin{array}{l}\text { Currais } \\
\text { Novos }\end{array}$ & 71,783 & 94,333 & 0.91 & 863.1 & 83.3 & -2.14 & 0.84 & 2.53 \\
\hline $\begin{array}{l}\text { Mossoroens } \\
\mathrm{e}\end{array}$ & 291,427 & 521,949 & 1.96 & 1775.3 & 54.1 & 2.56 & 0.09 & 5.71 \\
\hline TOTAL RN & $1,550,244$ & $2,771,000$ & 1.95 & 2,291 & 51.9 & 4.25 & 2.07 & 6.09 \\
\hline
\end{tabular}

The large economic and population growth in the capital zone contrasts sharply with the developments in the zones that are mainly in the Sertão and where income opportunities are limited, droughts are frequent, and social protection programs are few. A large share of the population in the five zones that are almost completely in the Sertão migrated to the metropolitan area, which resulted in a population growth in these zones of less than a third of the average population growth in the state of 79 percent, and a sixth of the capital zone's. Income growth followed the same path, but it was steeper because in three zones (Serras Centrais, Caicó, and Currais Novos) income contracted rather than grew during the last 30 years. Low-growth agriculture played a key role, and the main causes were the steep decline in cotton production and the end of traditional mineral extraction.

Poverty is rampant among families left in the zones from which there has been strong migration. More than 80 percent of the household heads had incomes less than one minimum salary in Serras Centrais and Currais Novos, compared to the zone average of 51 percent, or the capital zone's 44 percent. Carió, also in the Sertão, is the exception to this stark picture, but still did not have high economic growth or low migration. Caicó had the lowest proportion of people earning less than a minimum salary ( 26 percent) in $\mathrm{RN}$, but this cannot be explained by economic development, because the zone was just as hard hit as the other zones by factors such as the collapse of cotton cultivation. The difference may have been due to social development, including participation (see Chapter 4). This indicates that changes are more complex than just migration, and an alternative livelihood is needed in the rural areas. 
This clearly shows that regional disparities in Brazil extend beyond the differences between the Northeast and Southeast. There are sharp differences between the fast- and slow-growing zones within RN. This is very clear also from income per capita, which in the poor zones is only a quarter of that in the capital region. However, as Table 4.3 also shows, poverty is not only a rural phenomenon - 44 percent of heads of households in Litoral Oriental earn less than one minimum salary.

\section{Convergence Analyses}

This section analyzes whether: poor municipalities are catching up with rich municipalities, geography matters in the economic growth process, and must poor municipalities remain poor or can they become rich.

\subsection{Unconditional Convergence}

Barro and Sala-i-Martin (1995) work with two concept of convergence: unconditional convergence (or absolute convergence) and conditional convergence. The first concept can be analyzed in two ways: $\beta$ - and $\sigma$-convergence. $\beta$-convergence occurs when countries (regions) converge to the same level of per-capita income. When the dispersion of per-capita income are reduced over time, that is $\sigma$ - convergence. The second concept is applied to detect whether different policies can generate different equilibria in percapita income, hence each country or region converges to a particular level of per-capita income (there is not absolute convergence).

The $\beta$-convergence hypothesis can be tested in several ways. Following Barro and Salai-Martin (1995), the approach to convergence applies cross-section regression analyses of the average growth rates of real per-capita income on initial levels of the per-capita income:

$$
\frac{1}{\mathrm{~T}} \log \left(\frac{\mathrm{y}_{\mathrm{i}, \mathrm{t} 0+\mathrm{T}}}{\mathrm{y}_{\mathrm{i}, \mathrm{t} 0}}\right)=\alpha-\left(\frac{1-\mathrm{e}^{-\beta \mathrm{T}}}{\mathrm{T}}\right) \log \left(\mathrm{y}_{\mathrm{i}, \mathrm{t} 0}\right)+\varepsilon_{\mathrm{t}}
$$

Where $y_{t}$ is the municipality per-capita income $i$, in t time, $\alpha$ is a constant, $\beta$ is the converge parameter and $\varepsilon$ is a random disturbance term. We estimate (1) using the nonlinear least square (NLS) estimation method and heteroskedasticity robust standard errors according to White's (1980) procedure.

\section{Findings}

Convergence in its simplest form analyzes whether poor regions catch up with rich regions or, put differently, whether the rate of growth depends the initial level of percapita income. A negative association between per-capita incomes and the rates of growth means that per-capita incomes tend to converge absolutely, the so-called absolute convergence. If that negative association does not exist, absolute convergence does not 
exist. However, if after taking into account the influence of other variables, the negative association exists, then per-capita incomes tend to converge conditionally, the so-called conditional convergence.

In absolute convergence, the inverse relationship originates in a production function with diminishing returns: regions with lower per capita output would grow faster than regions with higher per capita output because the marginal product of capital would be higher in the former. A study by Cavalcanti and de Goes (1996) of absolute convergence for Brazilian states concludes that, on average, there is convergence, although it is very slow. In fact, the study finds that it would take about 90 years for Brazilian states to reach their steady state level of GDP, longer than what has been found, for example, for the states of the United States or for Spanish autonomous communities (comunidades autônomas).

Findings reveal that poor municipalities are not catching up with high-income municipalities in RN (Table 5.1). The relationship between 1970-96 growth and initial per-capita income based on 150 municipalities is hazily negative and reveals a very small rate of convergence in $\mathrm{RN}$ (Table 5.1). The estimates of the speed of convergence is incredibly small and implies that it takes about 170 years to eliminate one-half of the initial gap in per capita GDP. ${ }^{6}$ Hence, even if RN as a whole is catching up with other states in Brazil, there are strong forces within the state itself that leave poor municipalities behind in the growth process.

\begin{tabular}{|c|c|c|c|c|}
\hline \multicolumn{5}{|c|}{$\begin{array}{l}\text { Table 5.1: Convergence in RN (1970-96) } \\
\text { Dependent Variable: GDP Growth Rate }\end{array}$} \\
\hline Parameter & Coefficient & Std. Error & t-Statistic & Prob. \\
\hline$\hat{\alpha}$ & 0.066 & 0.0027 & 23.07 & 0.00 \\
\hline$\hat{\beta}$ & 0.004 & 0.0004 & 8.43 & 0.00 \\
\hline $\mathrm{R}-\mathrm{sc}$ & 0.35 & \multicolumn{3}{|c|}{ Mean dependent var 0.03} \\
\hline Adjusted R-sc & 0.34 & \multicolumn{3}{|c|}{ S.D. dependent var 0.02} \\
\hline S.E. of regressior & 0.017 & \multirow{2}{*}{\multicolumn{3}{|c|}{ Akaike info criterion -5.28}} \\
\hline F-statistic & 0.04 & & & \\
\hline Prob (F-statistic & 398.1 & \multicolumn{3}{|c|}{ Durbin-Watson stat 1.69} \\
\hline
\end{tabular}

Figure 5.2 Convergence Across Municipalities, Rio Grande do Norte

\footnotetext{
${ }^{6}$ The half-life is calculated using the formula: $t \approx 0.69 / \beta \approx 172.5$ ( see Romer, 2001 .pp. 25 )
} 


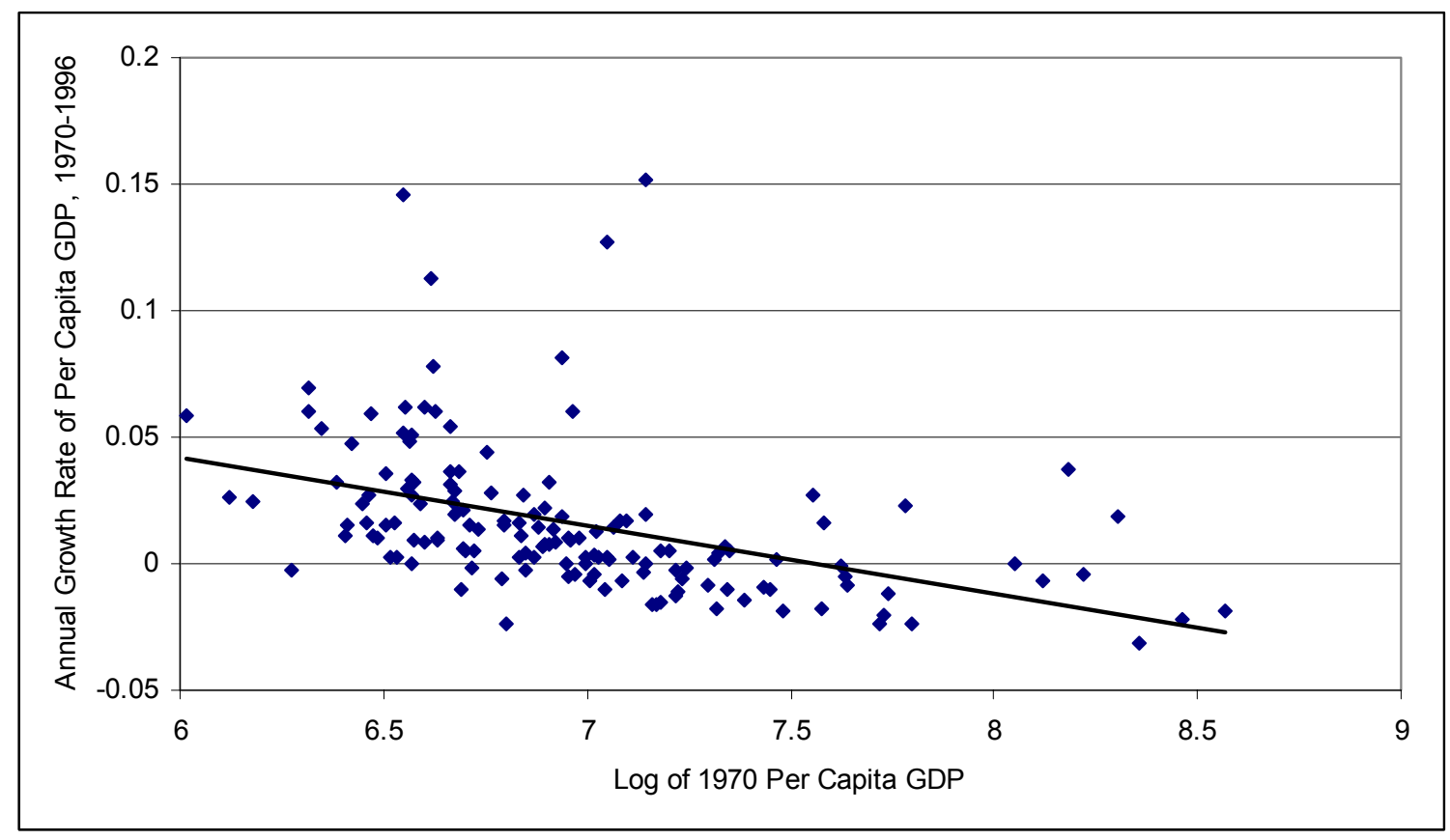

\section{$5.2 \sigma$-convergence}

This section evaluates $\sigma$-convergence for Rio Grande do Norte's municipalities by working with a normalized vector of per-capita income ${ }^{7}$. Figure 5.2 shows crossmunicipality standard deviations of per-capita income.

The dispersion or $\sigma$-convergence of per-capita income for RN's municipalities shows cross-municipality standard deviations increased during 1975-96 (from 0.40 to 0.47). This suggests that the growth process in the municipalities is accompanied by perturbations, which increase the dispersion of per-capita income among the municipalities. These findings also indicate that municipalities with lower initial income do not grow faster than municipalities with high initial income and, furthermore, that the cross-section dispersion of per-capita income does not collapse as time passes. Hence, the pattern of growth among municipalities is very different from what Cavalcanti and de Goes (1996) found among Brazilian states, which are converging in terms of income and, furthermore, the dispersion is diminishing. However, this finding is not very surprising, as other researchers have found similar results in other regions (Quah 1993).

\footnotetext{
${ }^{7}$ Over time, some municipalities show high and inexplicable variations in per-capita income, e.g., it increased ten times between 1970 and 1980 and returned to $100 \%$ of initial level in 1996. Because of this, some municipalities were excluded from the sample to calculate the $\sigma$ convergence.
} 
Figure 5.3 Sigma Convergence for Rio Grande do Norte Municipalities' Real Per-capita Income (1970-96)

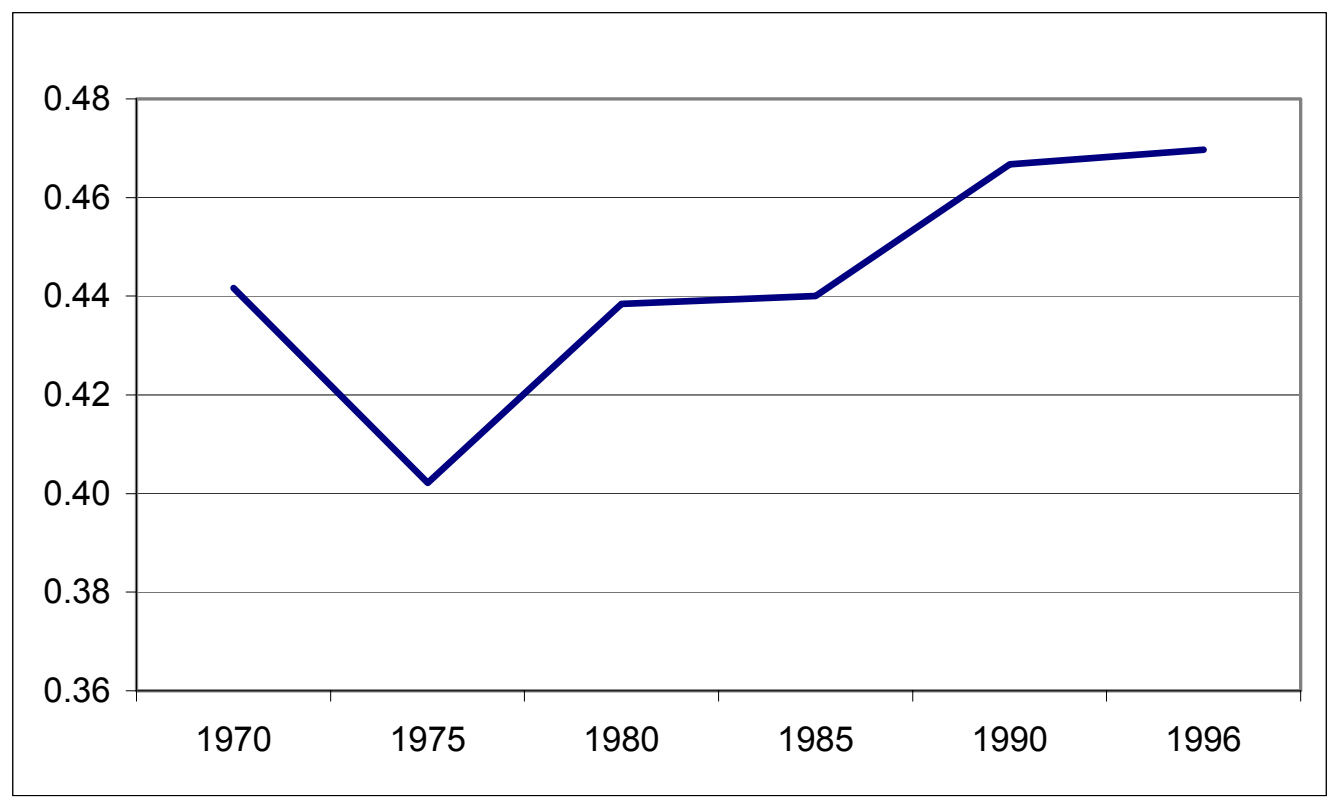

Source: author's calculations.

Several papers have identified a number of econometrics problems with this type of analysis. According to Kuper (1997), the traditional tools used to analyze convergence are not appropriate because "convergence is, by definition, a dynamic concept which cannot by captured by cross section studies". Moreover, according to Durlauf and Quah (1998), $\sigma$-convergence does not permit to evaluate the dynamics of cross section distribution over time and says nothing on whether clusters form within the cross section and on whether transitions occur within distribution. To avoid the above-mentioned problems, we apply the spatial statistic methodology and ask whether geography within $\mathrm{RN}$ plays a role in the growth process.

\subsection{Convergence by Spatial Statistic Perspective}

According to Quah (1993), it is necessary to evaluate convergence to understand the role of the space in the growth path. In addition, Gallup et al. (1998) argue that location and climate have large effects on income levels and growth. It is also argued that economic activity may agglomerate at some locations with the striking implication that two regions with similar characteristics may end up developing totally different economic structure (see Mossi et al. 2001).

Tools of spatial econometrics have been developed and recent studies have presented several ways to analyze the possibility of the existence of spatial correlation in a variable across distinct areas. A variable is called "spatially correlated" when the observed values in adjacent areas are more similar. 
We work with two approaches to evaluate spatial dependence. The first one is a global measure of spatial dependence suggested by Moran (1950), and it is named the Moran index (MI). The second approach, developed by Quah (1993), deals with the transitional dynamics and allows us to evaluate the probability that a municipality will shift from a poor (rich) income bracket to a rich (poor) income bracket.

\section{Moran Index}

Do poor municipalities neighbor poor municipalities, and rich neighbor rich? It is widely accepted that location and climate have large effects on income levels and growth through their effects on the distance from markets, transport costs, and agricultural productivity among other channels. This section analyzes the possibility of the existence of spatial correlation among distinct areas in $\mathrm{RN}$. When the observed values in adjacent areas are similar they are said to be "spatially correlated."

The Moran Index is distributed between 1 and -1 . Values around zero indicate that there is no spatial dependence, values around 1 represent strong and positive spatial dependence and can be represented by the equation below:

$$
M I=\frac{n}{\sum_{i} \sum_{j} w_{i j}} * \frac{\sum_{i} \sum_{j} w_{i j}\left(y_{i}\right)\left(y_{j}\right)}{\sum_{i}\left(y_{i}\right)^{2}}
$$

Where $\mathrm{n}$ is a number of municipalities, $\mathrm{w}_{\mathrm{ij}}$ are the elements of a binary contiguity matrix $\mathrm{W}_{\mathrm{nxn}}$, taking value 1 if the municipalities $\mathrm{i}$ and $\mathrm{j}$ share a common border and 0 if they do not; $y$ is a standardized vector of the per-capita income of each municipality.

The evolution of the MI and the standard error of per-capita income in RN's municipalities ( $\sigma$-convergence) are shown in Figure 5.2 (and Table A1 in appendix). The evolution in RN's municipalities indicates that the value has marginally increased-over the past three decades the MI increased from 0.25 in 1970 to 0.30 in 1996. This indicates that the positive spatial dependence among municipalities is increasing over time in RN. In other words, rich municipalities neighbor rich municipalities, and poor neighbor poor. 
Figure 5.4 Moran Index (MI) and Sigma Convergence for Municipalities in Rio Grande do Norte's per-capita Income (1970-96)

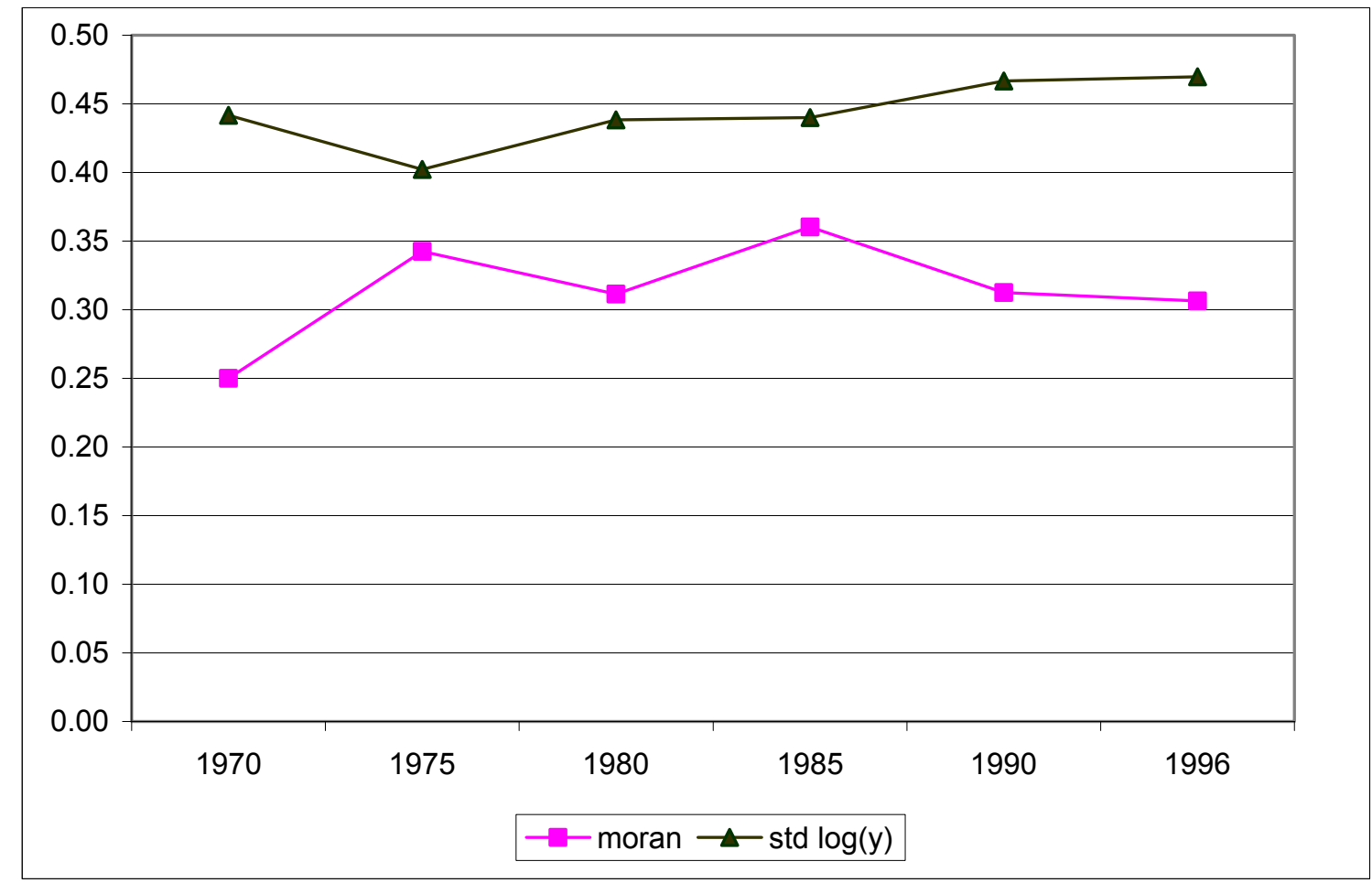

Source: authors calculations.

Figure 5.4, furthermore, suggests a negative correlation between Moran Index and the standard errors of per-capita income over time. According to Rey and Montouri (1999), apud Mossi et al. (2001): "this co-movement may reflect a dynamic characteristic of regional clustering and two possible explanations may support this fact. On the one hand, an increase in spatial dependence could be due to regions in each cluster becoming more similar. On the other hand, it could be due to newly formed clusters emerging during a period of increasing income dispersion". That is, when rich (poor) municipalities are surrounded by rich (poor) municipalities, in a cluster, the income dispersion increases among municipalities.

\subsection{Transitional Dynamics}

Recent literature on economic growth has used the transition matrix to deal with transitional dynamic, see Quah (1993). According to Kremer (2001), this methodology allows a more flexible relationship between the level of income and growth rate of income than the standard convergence approach in which countries' or regions' growth rate are assumed to be a linear function of their income levels. 
Following Quah (1993), it is assumed that the income of each municipality follows a first-order Markov Process with time-invariant transition probabilities. This is, a municipality's income of tomorrow depends only on its income of today. In this way, let $\mathrm{F}_{\mathrm{t}}$ denotes the distribution of incomes across municipalities at time $t$ and the law motion can define its evolution:

$$
\mathrm{F}_{\mathrm{t}+1}=\mathrm{MF}_{\mathrm{t}}
$$

Where M maps one distribution into another and encodes information on whether poor (rich) economies transit from $\mathrm{t}$ time to $\mathrm{t}+1$ to widely different income levels.

In the discrete version of this approach, we can take each of Rio Grande do Norte's municipality per-capita income relative to the State average and divide municipalities into income groups. Quah (1993) suggests dividing the observed data into approximately equally sized categories. We divide the data in five groups: poor (P), low (L), medium $(\mathrm{M})$, upper (U) and rich (R) municipalities. ${ }^{8}$ Consequently, $\mathrm{M}$ is described by a $5 \times 5$ Markov Chain Transition matrix, whose $(\mathrm{j}, \mathrm{k})$ entry is the probability that a municipality in state $\mathrm{j}$ in time $\mathrm{t}$ transits to state $\mathrm{k}$ in time $\mathrm{t}+\mathrm{s}$. The main diagonal of this matrix denotes persistence, as it represents the probability for a municipality remaining in its original group.

We estimate the transition matrix using per-capita income data for 150 of Rio Grande do Norte's municipalities from 1970 to 1996. It is important to observe that the range for groups was calculated in each moment of time, as it is necessary to analyze the relative position of each municipality over time to avoid biases, since all municipalities show absolute per-capita income growth over time, but not necessarily a change in their relative position.

Quah (1993) built the one-step annual transition matrix, estimated by averaging the observed one-year transitions over every year, and one 23-year transition with data of initial and final time of his sample. However, the literature suggests that the choice of time interval may affect the probabilities, in other words, the transition matrix is very sensitive to time lag. According to Kremer et al. (2001), transition periods longer than one year reduce the impact on the estimated transition matrix of high fluctuations in income and, consequently, the results are more robust. On the other hand, the longer the transition period is, the higher the mobility among classes. Hence, we construct a matrix with a 26-year transition, the maximum that our data allow.

\footnotetext{
${ }^{8}$ Poor $(\mathrm{P})=0-\left(\mu-0.45^{*} \sigma\right)$; Low $(\mathrm{L})=\left(\mu-0.45^{*} \sigma\right)-\left(\mu-0.30^{*} \sigma\right)$; Medium $(\mathrm{M})=(\mu-0.30 * \sigma)-(\mu$ $-0.10 * \sigma)$, Upper $(\mathrm{U})=(\mu-0.10 * \sigma)-(\mu+0.20 * \sigma)$ and Rich $(\mathrm{R})=>(\mu+0.20 * \sigma)$ where: $\mu$ is the percapita income mean in the year $i$ and $\sigma$ is the standard error of per-capita income in the year $i$.
} 


\begin{tabular}{|c|c|c|c|c|c|c|}
\hline \multicolumn{7}{|c|}{$\begin{array}{l}\text { Table 5.2: 26-year Transition Matrix, RN } \\
\qquad(1970-96)\end{array}$} \\
\hline \multirow{7}{*}{ 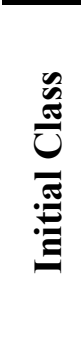 } & Income & & & ind Cla & & \\
\hline & Class & $\mathbf{P}$ & $\mathbf{L}$ & M & $\mathbf{U}$ & $\mathbf{R}$ \\
\hline & $\mathbf{P}$ & 0.27 & 0.15 & 0.31 & 0.23 & 0.04 \\
\hline & $\mathbf{L}$ & 0.38 & 0.21 & 0.09 & 0.15 & 0.18 \\
\hline & M & 0.32 & 0.15 & 0.26 & 0.12 & 0.15 \\
\hline & $\mathbf{U}$ & 0.30 & 0.10 & 0.27 & 0.13 & 0.20 \\
\hline & $\mathrm{R}$ & 0.23 & 0.12 & 0.04 & 0.12 & 0.50 \\
\hline
\end{tabular}

Must poor municipalities remain poor or can they become rich? Over a 26-year horizon, there is a large amount of transition. ${ }^{9}$ The probability that a municipality will shift from a low- to a high-income class, from group P (poor) to R (rich), is low (4 percent), and vice versa (Table 5.2).

Municipalities in middle-income classes L, M, and $U$ are highly mobile, and they have a higher likelihood of becoming poor than rich. For example, for a medium-income municipality the likelihood is 32 percent that it will become poor and 15 percent that it will become rich.

\subsection{Ergodic Distribution}

Do convergence clubs exist in RN? This is address here using an ergodic distribution. The vector of ergodic probabilities can be viewed as indicating the unconditional probabilities of each of the $\mathrm{k}$ different states, that is, independently of the initial state. According to Hamilton (1994), it can be showed that if $\mathrm{M}$ is the transition matrix ${ }^{10}$, then:

$$
\mathrm{M}^{*}=\operatorname{Lim}_{n \rightarrow \infty} M^{n}=\pi L^{\prime}
$$

\footnotetext{
${ }^{9}$ Recent literature on economic growth has used the transition matrix to deal with transitional dynamic (see Quah 1993). According to Kremer, Onatshi, and Sotch (2001), this methodology allows a more flexible relationship between the level of income and growth rate of income than the standard convergence approach in which countries' or regions' growth rates are assumed to be a linear function of their income levels. For more details on RN see Tebaldi and Verner (2001)

${ }^{10}$ It is assumed that $\mathrm{M}$ is an ergodic Markov Chain.
} 
Where $\pi$ denotes the vector of ergodic probabilities and $\mathrm{L}$ is a $(\mathrm{kx} 1)$ vector of $1 \mathrm{~s}$. In this way, it can be used as the concept of convergence in probability ${ }^{11}$ to acquire $\pi$, which is any row of $\mathrm{M}^{*}$.

\begin{tabular}{|c|c|c|c|c|c|}
\hline \multicolumn{6}{|c|}{$\begin{array}{l}\text { Table 5.3: Distribution for 5-Year an } \\
\text { Transition Matrix for RN (1970-96) }\end{array}$} \\
\hline Period & $\mathbf{P}$ & $\mathbf{L}$ & M & $\mathbf{U}$ & $\mathbf{R}$ \\
\hline 5-year & 0.34 & 0.14 & 0.20 & 0.15 & 0.18 \\
\hline 26-year & 0.29 & 0.14 & 0.21 & 0.16 & 0.20 \\
\hline
\end{tabular}

Convergence clubs exist among municipalities even though no absolute convergence is present in RN. The distribution obtained from estimation of transition matrixes shows probabilities perceived independently of the transition periods (Table 5.3). ${ }^{12}$ For the 26year transition, a peak is present in the poor $(\mathrm{P})$ income category, which contains nearly 30 percent of all the municipalities and, furthermore, about 20 percent of municipalities are in the richest income group $(\mathrm{R})$. These findings indicate that convergence clubs exist in $\mathrm{RN}$, but no absolute convergence is taking place.

The lack of convergence - the migration and sectoral development pattern away from low-growth agriculture in the Sertão Zones toward services in the capital region-have implications for policies. Policies in the two geographical areas should (a) assist the people remaining behind, that is, rural families remaining in the poor municipalities mainly in the Sertão, so they will have education or skills that will enable them to choose to stay or leave, and not be forced by lack of opportunities due to insufficient skills, and (b) assist the poor migrants that lack skills to integrate fully into the modern economy in the urban areas.

Among the policies for rural families should be an improvement of the design of education strategies, including ways to upgrade work skills. In addition, small farmers would benefit from improved access to technical assistance, and recent migrants would benefit from increased access to education that focuses particularly on their needs. This would include programs that concentrate on closing the gap in education for both adults and children.

\footnotetext{
11 For more details on this concept, see Hamilton (1994) pg. 749.

12 The vector of ergodic probabilities can be viewed as indicating the unconditional probabilities of each of the different states, that is, independent of the initial state.
} 


\section{Conclusions}

The traditional convergence analysis indicates that countries or states with lower initial income grow faster than those with high initial income. Findings reveal that the crosssection dispersion of municipal per capita income does not collapse but rather the contrary, it increases over time in Rio Grande do Norte. Although our analyses indicate some spatial dependence in income, the indicator is small and has a downward trend indicating that the growth path is only weakly determined by geographical links in Rio Grande do Norte. The dynamic analysis, based on the Markov chain transition matrix, shows that the probability of a municipality moving from a poor income class to a rich one is very small and vice-versa. The middle-income class municipality has high mobility, but there is no strong evidence indicating the direction. There are signs in the data of convergence clubs; a poor and rich a club. Hence, policies in the two geographical areas should (a) assist the people who are behind. That is, rural families who remain in the poor municipalities such as Sertão, be provided with education or skills that will enable them to choose to stay or leave, and not be forced by lack of opportunities due to insufficient skills, and (b) assist the poor and/or unskilled migrants to integrate fully into the modern economy in the urban areas. 


\section{References}

Abreu, M. and Verner, D. (1997). Long-term Brazilian Economic Growth: 1930-94. OECD Development Centre.

Barro, R. and Sala-i-Martin, X. (1995). "Economic Growth". The MIT Press, Massachusetts.

Cavalcanti and de Goes (1996).

Durlauf, S. and Quah, D. (1998). "The New Empirics of Economic growth". National Bureau of Economic Research. Working Paper No 6422.

Gallup, J. L. , Sachs, J.D and Mellinger, A. D. (1998). "Geography and Economic Development" NBER Working Paper No. 6849.

Hamilton, J. D. (1994). Time Series Analysis. Princeton University Press. New Jersey.

Kremer, M., Onatski, A. and Stock, J. (2001). "Searching for prosperity". National Bureau of Economic Research. Working Paper No 8250.

Kuper, G. H. (1997). "Convergence and Cross-section Dynamics: Evidence from the data”. Working Paper:

http://papers.ssrn.com/sol3/delivery.cfm/9706301.pdf?abstractid=1680

Mossi, M. B., Aroca, P., Fernández, I. and Azzoni, C. (2001). "Growth Dynamics and Space in Brazil".

Quah, D. (1993). "Empirical cross-section dynamics in economic growth". European Economic Review, 37. North Holland.

Rey, S. and Montouri, B. (1999). "US regional Income Convergence: A spatial Econometric Perspective". Regional Studies, 33:2, 143-156.

Romer, David. (2001). Advanced Macroeconomics. McGraw-Hill, New York.

White, H. (1980). "A Heteroskedasticity-Consistent Covariance Matrix and a Direct Test for Heteroskedasticity," Econometrica, 48, 817-838. 
Table A1: Moran Index Vs Sigma

Convergence - 1970-1996

\begin{tabular}{ccc}
\hline Year & Moran Index & Std. Error log(y) \\
\hline 1970 & 0.250 & 0.442 \\
1975 & 0.342 & 0.402 \\
1980 & 0.312 & 0.438 \\
1985 & 0.360 & 0.440 \\
1990 & 0.312 & 0.467 \\
1996 & 0.307 & 0.470 \\
\hline
\end{tabular}

Source: Calculated by authors

Table A2: Codes of the zones in Rio Grande do Norte

\begin{tabular}{cc}
\hline Code & Name of the zones \\
\hline 1 & Zona do Litoral Oriental \\
2 & Zona do Litoral Norte \\
3 & Zona do Agreste \\
4 & Zona de Currais Novos \\
5 & Zona de Caicó \\
6 & Zona das Serras Centrais \\
7 & Zona do Alto do Apodi \\
8 & Zona Mossoroense \\
\hline
\end{tabular}

